\title{
Isothermal and non-isothermal infiltration and deuterium transport: a case study in a soil column from a headwater catchment
}

\author{
Martina Sobotková $^{1 *}$, Michal Sněhota ${ }^{1,2}$, Eva Budínová ${ }^{1}$, Miroslav Tesař ${ }^{3}$ \\ ${ }^{1}$ Czech Technical University in Prague, Faculty of Civil Engineering, Department of Drainage and Landscape Engineering, Thákurova 7 , \\ Prague 6, 166 29, Czech Republic. \\ ${ }^{2}$ Czech Technical University in Prague, University Centre for Energy Efficient Buildings, Třinecká 1024, Buštěhrad, 273 43, Czech \\ Republic. \\ ${ }^{3}$ Institute of Hydrodynamics of the Czech Academy of Sciences, Pod Pat'ankou 30/5, 16612 Prague 6, Czech Republic. \\ * Corresponding author. Tel.: +420 224354775. E-mail: martina.sobotkova@fsv.cvut.cz
}

\begin{abstract}
Isothermal and non-isothermal infiltration experiments with tracer breakthrough were carried out in the laboratory on one intact column $(18.9 \mathrm{~cm}$ in diameter, $25 \mathrm{~cm}$ in height) of sandy loam soil. For the isothermal experiment, the temperature of the infiltrating water was $20^{\circ} \mathrm{C}$ to the initial temperature of the sample. For the two non-isothermal experiments water temperature was set at $8^{\circ} \mathrm{C}$ and $6^{\circ} \mathrm{C}$, while the initial temperature of the sample was $22^{\circ} \mathrm{C}$. The experiments were conducted under the same initial and boundary conditions. Pressure heads and temperatures were monitored in two depths $(8.8$ and $15.3 \mathrm{~cm})$ inside the soil sample. Two additional temperature sensors monitored the entering and leaving temperatures of the water. Water drained freely through the perforated plate at the bottom of the sample by gravity and outflow was measured using a tipping bucket flowmeter. The permeability of the sample calculated for steady state stages of the experiment showed that the significant difference between water flow rates recorded during the two experiments could not only be justified by temperature induced changes of the water viscosity and density. The observed data points of the breakthrough curve were successfully fitted using the two-region physical non-equilibrium model. The results of the breakthrough curves showed similar asymmetric shapes under isothermal and non-isothermal conditions.
\end{abstract}

Keywords: Isothermal infiltration; Non-isothermal infiltration; Column leaching; Breakthrough curve; Deuterium; Viscosity; Capillary trapping; Entrapped air; Permeability.

\section{INTRODUCTION}

Many subsurface hydrological processes of engineering and environmental relevance occur under near-saturated conditions. These processes involve infiltration into the topsoil during high-intensity rainfalls (Angulo-Jaramillo et al., 2016), surfacegroundwater interaction in landscape depression with ponds (Gerke et al., 2010), water flow, solute and oxygen transport across the capillary fringes (Haberer et al., 2011; Silliman et al., 2002) and in natural and constructed wetlands (Gerla, 1992), and tidal periodic occurrence of capillary fringe in coastal aquifers (Nielsen et al., 1997). However, the current models often fail to predict water flow and solute transport in the nearsaturated porous medium as the assumptions of those models are not fully fulfilled. The effects of particular importance occurring close to saturation are air trapping (Faybishenko, 1995) and preferential flow (Koestel and Jorda, 2014).

Moreover, in the upper soil layer the temperature can vary significantly which may influence water flow (Braga et al., 2007). Many processes affected by the transfer of heat in the shallow subsurface is reflected in numerous simulation studies (e.g., Buchner et al., 2008; Saito et al., 2006). Importantly, temperature changes affect the soil hydraulic properties and therefore water flow.

The effect of water temperature on the rate of infiltration was studied by Duley and Domingo (1943) in an experimental study of water flow in packed samples of glass beads and sandy loam soil. They conducted infiltration of water at different temperatures. An increase in the infiltration rate was observed with water at a temperature of $43^{\circ} \mathrm{C}$, while no significant changes were found when the temperature of the water was set to a temperature in the range from $4^{\circ} \mathrm{C}$ to $21^{\circ} \mathrm{C}$. The increase in the hydraulic conductivity with the higher temperature of infiltrating water and lower viscosity was observed by e.g. Haridasan and Jensen (1972), Saha and Tripathi (1979), or Hopmans and Dane (1986). Changes in the hydraulic conductivity of the surface layer due to changes in the viscosity in response to diurnal temperature changes which caused variations in the infiltration rate were studied also by Jaynes (1990). They measured the infiltration rate and temperature during 5 days in the field plot. They found that the infiltration rate varied from 14.5 to $26.9 \mathrm{~mm} / \mathrm{h}$ with the corresponding variation in temperatures from 14.9 to $31.5^{\circ} \mathrm{C}$.

Infiltration experiments on repacked sand and loam columns were carried out by Constanz and Murphy (1991) for water at temperatures of 5,25 , and $60^{\circ} \mathrm{C}$. They found an increase of infiltration rates of at least $300 \%$ between 5 and $60^{\circ} \mathrm{C}$. Their findings were compared with a simple temperature-sensitive modification to the Green and Ampt infiltration equation. They found a good agreement between the measured and predicted initial infiltration rates at $25^{\circ} \mathrm{C}$ for both soil materials. They also noticed increased water saturation with higher temperatures. The final infiltration rates at 25 and $60^{\circ} \mathrm{C}$ were accurately predicted using the modified Green and Ampt equation. They concluded that the influence of temperature on infiltration rates was fully accounted for by considering the temperature dependence of the viscosity of liquid water.

Recently, Braga et al. (2007) reported that the variation of the infiltration rate with increasing temperature in site with silty loam soil was higher than that predicted from liquid viscosity changes themselves, suggesting the possible involvement of other temperature dependent factors, possibly the effect of the expansion of entrapped air bubbles. Lin et al. (2003) observed a significant dependence of the infiltration rate on the tempera- 
ture within a long-term 4-year study of infiltration in a largescale effluent recharge plant. In their study, the infiltration rates exceeded those predicted by temperature induced change in water viscosity by a factor of 1.5 to 2.5 . Hopmans and Dane (1986) reported that the entrapped air volume decreased with increasing temperature, which is in direct contradiction to the theory of gas solubility. In the same study, measured retention curves showed significant hysteresis and strong temperature effects beyond those calculated by incorporating viscosity and surface tension effects.

The above summary of the existing literature suggests that despite the fact that the topic of temperature effects on water infiltration in soil has been revisited many times, some results contradict other and the topic still requires attention. It is reasonable to assume that entrapped air and temperature changes may affect both the water infiltration and the solute transport. We hypothesize that the decrease of air solubility in water related to its temperature increase can cause the formation of trapped air bubbles when cold water infiltrates into warmer soil. Such a situation occurs when cold rainwater infiltrates into warmer soils during the summer season. The growth of bubbles may then restrict the water flow and consequently cause a decrease of the infiltration rate. Non-homogeneously distributed growth of bubbles may then lead to changes of solute breakthrough characteristics. Therefore a ponded infiltration experiment with tracer breakthrough was conducted in this study on a sample of heterogeneous soil from a headwater catchment under both near-isothermal and non-isothermal conditions to study the effect of temperature change on water flow and solute transport.

Objectives of the study were twofold: (i) to examine the effect of the gradient between the temperature of infiltrating water and soil temperature on water infiltration, and (ii) to assess the effect of the thermal gradient on the shape of the tracer breakthrough.

\section{MATERIALS AND METHODS Site characterization}

The intact soil column was extracted in the mountainous catchment at the experimental site Roklan (Sumava Mountains, Czech Republic; latitude 48 $58^{\prime} 32.483^{\prime \prime} \mathrm{N}$ and longitude $13^{\circ} 25^{\prime} 47.679^{\prime \prime}$ E, 1224 m a.s.1.). The Roklan experimental catchment, also referred to as Kout (Tesař et al., 2006; 2008), is located in the National Park of Sumava, Czech Republic. The area of the catchment is $0.1 \mathrm{~km}^{2}$. In the period of 1992 and 2000 , the Roklan site was deforested due to bark beetle infestation and currently, the forest is growing back naturally. The prevailing tree species is spruce with an undercover of Calamagrostis villosa. The mean annual precipitation ranges from 800 to $1600 \mathrm{~mm}$ and the mean annual air temperature is from 3 to $6^{\circ} \mathrm{C}$. The soil type was classified as acid brown soil developed on metamorphosed rocks - paragneiss (Tesař et al., 2006; 2008). The site is equipped with a meteorological station, soil tensiometers, and soil water content sensors. Water content data show that the soil saturates several times a year in response to rainfall events.

\section{Soil properties}

Soil water retention curves were determined on triplicates of small undisturbed soil samples $\left(100 \mathrm{~cm}^{3}\right)$ taken in $15,30,45$ and $60 \mathrm{~cm}$ depths. The combination of sand tank apparatus and pressure plate extractor were applied to develop the soil water potential - water content relationship (Jury and Horton, 2004).
Measured points were fitted using the RETC code (van Genuchten et al., 1991) equation to obtain the parameters of the van Genuchten model (van Genuchten, 1980). Particle-size distribution was analyzed in a grab soil sample from a depth of $30 \mathrm{~cm}$, by the combination of sieving and sedimentation methods (Hillel, 1989). Particle density and porosity were analyzed on small undisturbed samples taken at the same depth.

\section{Collection of intact soil core}

The soil core was extracted from a depth of 20 to $45 \mathrm{~cm}$ (B horizon). The soil core was retrieved in a PVC plastic cylinder (internal diameter $18.9 \mathrm{~cm}, 25 \mathrm{~cm}$ height) using custom-made jack-operated coring equipment (Ungureanu et al., 2012). The hydraulic jack supported by a metal frame was used to gradually push the cylinder under the surface, while the surrounding soil was gradually removed to reduce friction. The column was then moved to a laboratory, and stored in a refrigerator until the time of sample treatment aimed at preventing bypass flow along the walls. To seal any gap between the wall and the sample, the sample was first left to slowly dry. The soil was then pushed out from the original PVC plastic cylinder using a hydraulic jack to a second cylinder of the same size positioned 2 $\mathrm{cm}$ above the original cylinder. The exposed soil surface was gradually coated with a finer fraction of the same soil, while all cavities were also filled with the fine material.

The sample was scanned through the use of x-ray computer tomography (CT) with a GE Phoenix v|tome|x m XRT scanner installed at the Department of Soil and Environment at the Swedish University of Agricultural Sciences (Uppsala), which has a $240 \mathrm{kV}$ X-ray tube, a tungsten target (beryllium window) and a GE 1600 flat panel detector. The resulting pixel size was $0.148 \times 0.148 \times 0.148 \mathrm{~mm}^{3}$. The imaging set-up is suitable for characterization of macropores in undisturbed soil samples (Larsbo et al., 2014). The inspection of images showed that the sample was compact, without the presence of sampling induced cracks, with the exception of cracks within $2 \mathrm{~cm}$ from the sample's perimeter.

\section{Laboratory setup to perform the near-isothermal and non-isothermal infiltration outflow experiments}

The existing automated laboratory set-up (Snehota et al., 2008; Sobotkova and Snehota, 2014) was modified to perform the isothermal and non-isothermal ponded infiltration-outflow experiments with the application of concentration pulse of deuterium. The experimental concept of ponded infiltration on a soil column suitable for the measurement of changes of saturated hydraulic conductivity follows the experiments by Císlerová et al. (1988).

In brief, the ponding level $(+0.5 \mathrm{~cm})$ at the top of the soil column was maintained by a water level sensor (Optical Liquid-Level Sensor, LV171, Omega Engineering) connected to a datalogger (CR850, Campbell Scientific). The bottom of the sample was supported by coarse stainless steel mesh and finer nylon fabric. Water and deuterium solution was delivered in the ponding water through multiple jets to achieve proper mixing. The soil column was installed on an aluminum frame that was placed on a load cell (LC 101-25, Omega Engineering) to monitor the mass of the sample. The effluent was continuously sampled from a U-shaped tube below the sample (Figure 1) through the use of a digital peristaltic pump (Reglo Digital 4 Channels, ISM 597 D, Ismatec $\left.{ }^{\circledR}\right)$. The pump delivered the effluent to a fraction collector (Retriever 500, Teledyne ISCO), in which samples were taken for $\mathrm{d}^{2} \mathrm{H}$ analysis. Water 


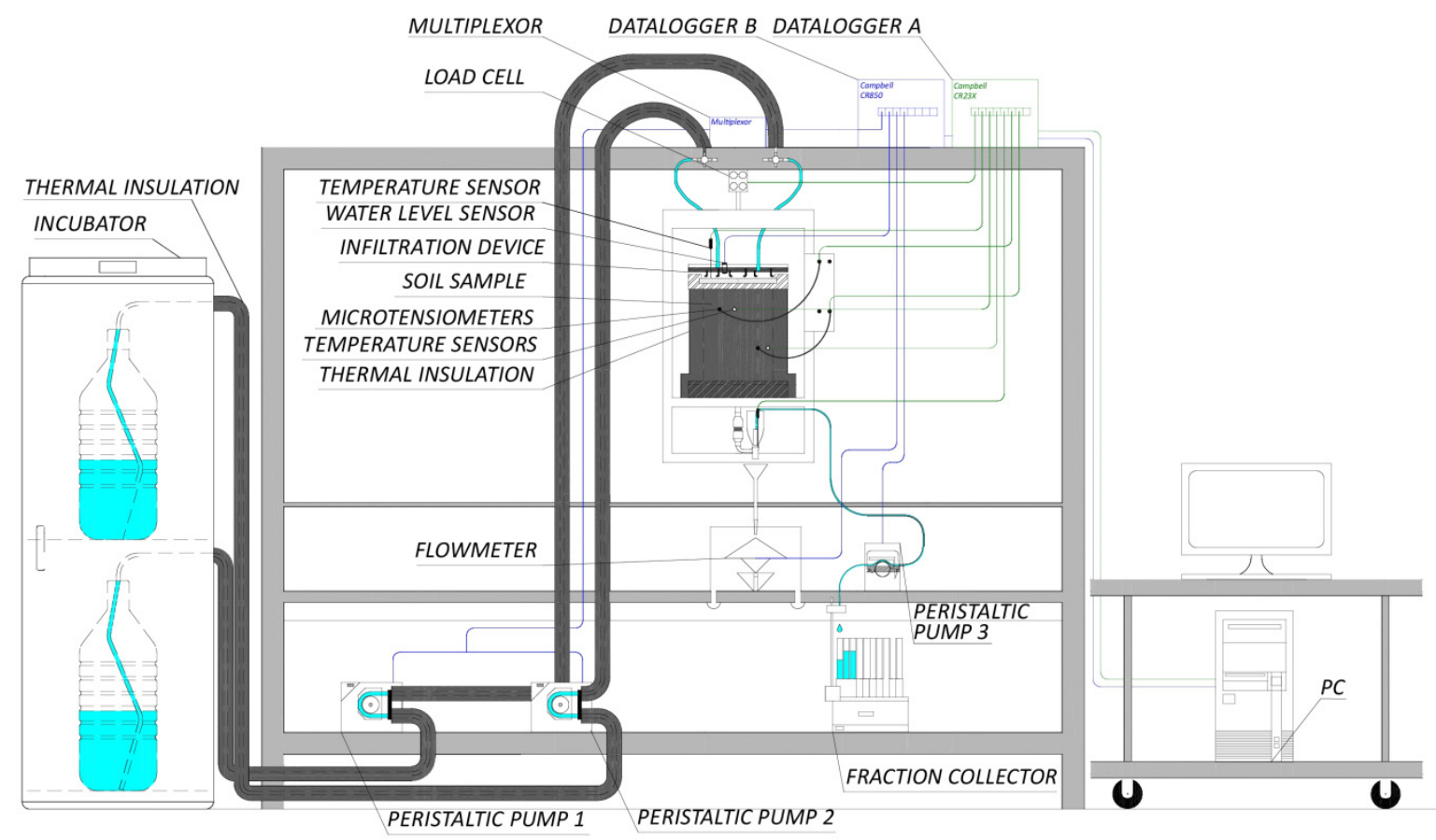

Fig. 1. Schematic view of the experimental set-up for performing isothermal and non-isothermal infiltration-outflow experiments.

flow was continuously measured by a tipping bucket weighed by a load cell (LC 101-25, Omega Engineering, Inc.). The walls of the plastic tube were covered by a $20 \mathrm{~mm}$ thick layer of polyethylene foam thermal insulation (Mirelon, thermal conductivity, $\lambda=0.046 \mathrm{~W} / \mathrm{m} . \mathrm{K}$ ) to ensure stable temperatures in the soil core. Subsequently, tubes leading to supply bottles were covered by $20 \mathrm{~mm}$ thick polyethylene thermal foam insulating the heat flux across the tubing walls. Supply bottles were placed into the incubator (Q-Cell 240/40 basic, Pol-Lab) with adjustable temperatures ranging from 3 to $40^{\circ} \mathrm{C}$.

Two microtensiometers (T5 UMS, GmbH München) and thin soil temperature sensors (109SS-L, thermistor Campbell Scientific, Logan, Utah) were inserted into the soil column to measure pressure heads and temperatures inside the soil core at depths of 8.8 and $15.3 \mathrm{~cm}$ below the soil surface. The temperature of inflow and outflow water was measured by the same type of temperature sensors. Because of the high content of stones, the stone-free position for all probes was located in the CT image before the probes were physically installed. The positions of all the sensors in relation to the inner structure of the sample are visible in Figure 2.

\section{Infiltration-outflow experiment with deuterium breakthrough}

The soil core surface was flooded with water to a level of about $+0.5 \mathrm{~cm}$ at the beginning of each infiltration experiment. Three experiments were conducted: (a) near-isothermal (R-I), with an infiltrating water temperature of $20^{\circ} \mathrm{C}$ and an initial soil temperature of $22^{\circ} \mathrm{C}$, (b) non-isothermal (R-N-1) in which water was delivered from the reservoir cooled to $8^{\circ} \mathrm{C}$ and (c) a non-isothermal infiltration experiment (R-N-2) with an initial water temperature of $6^{\circ} \mathrm{C}$ while the initial soil temperature was $22^{\circ} \mathrm{C}$. During quasi-steady state flow a concentration pulse of deuterium oxide was applied to the top of the sample for each experiment. For the isothermal (R-I) and non-isothermal (R-N-1 and R-N-2) infiltrations experiments, deionized water spiked with $15 \mathrm{mg} . \mathrm{L}^{-1} \mathrm{CaSO} 4\left(1.1 \times 10^{-4} \mathrm{M}\right)$ was used. During quasi-steady state flow, a pulse of a solution of $15 \mathrm{mg} . \mathrm{L}^{-1}$ CaSO4 $\left(1.1 \times 10^{-4} \mathrm{M}\right)$ and deuterium oxide $\left(100 \mathrm{mg} . \mathrm{L}^{-1}\right)$ was applied. Effluent samples were collected every $120 \mathrm{~s}$ by a fraction collector. Samples were analyzed for $\delta^{2} \mathrm{H}$ with a laser spectroscope (DLT-100, Los Gatos Research) for R-I and R-N-1. Changes in the amount of $\delta^{2} \mathrm{H}$ in solution were described as a depletion of the heavier isotope compared with the standard value (Penna et al., 2010). The pulse concentration of $\delta^{2} \mathrm{H}$ corresponds to $280 \%$ Vienna Standard Mean Ocean Water, IAEA, Vienna. Concentrations $\delta^{2} \mathrm{H}$ in the effluent were recalculated to the relative concentration $c / c_{o}$. The temperature and pressure heads were monitored every 5 seconds. Observations of cumulative fluxes, pressure heads, temperatures and breakthrough curves of $\delta^{2} \mathrm{H}$ over time were obtained.

\section{Transport model to evaluate transport parameters}

The one-dimensional transport code STANMOD (Studio of Analytical MODels) (Simunek et al., 1999; van Genuchten et al., 2012) coupled with a CXTFIT Code (Toride et al., 1995) was used to evaluate transport parameters of the two infiltration experiments. The two-region physical non-equilibrium model was used to fit deuterium breakthrough curves (BTCs) measured during the near-isothermal and non-isothermal infiltration experiments (R-I and R-N-1). The two-region model partitions the liquid phase into mobile (flowing) and immobile (stagnant) regions. In the mobile region, the advectiondispersion equation is used. The exchange of solute between the two regions is modeled as a first-order process.

The transport equation for the mobile and immobile water phases (van Genuchten, 1981) reads:

$$
\theta_{m} \frac{\partial c_{m}}{\partial t}+\theta_{i m} \frac{\partial c_{i m}}{\partial t}=\theta_{m} D \frac{\partial^{2} c_{m}}{\partial x^{2}}-\theta_{m} v_{m} \frac{\partial c_{m}}{\partial x}
$$




$$
\theta_{i m} \frac{\partial c_{i m}}{\partial t}=\alpha\left(c_{m}-c_{i m}\right)
$$

where $c_{m}$ and $c_{i m}$ refer to the concentration of mobile and immobile liquid regions, $v_{m}$ is the average pore water velocity in the mobile liquid phase. The mass transfer coefficient, $\alpha$, determines the rate of exchange between the two liquid phases.

The mean pore velocity, $v$, dispersivity, $\lambda$, fraction of mobile water, $f$, and mass transfer coefficient, $\alpha$, were optimized in the least-square sense. For both cases (R-I and R-N), different values of the initial estimates were tested to study the variability of the optimized parameters and the mean value was taken as an accurate estimation.

\section{Calculation of permeability}

The saturated hydraulic conductivity, $K_{s}$, was calculated based on the measured outflow rate during the stages of steadystate flow using Darcy's law for the steady-state stages of all three experiments. Then soil permeability $k\left(\mathrm{~m}^{-2}\right)$ was calculated using the standard formula (Constanz, 1982).

\section{a) $88 \mathrm{~mm}$} below surface
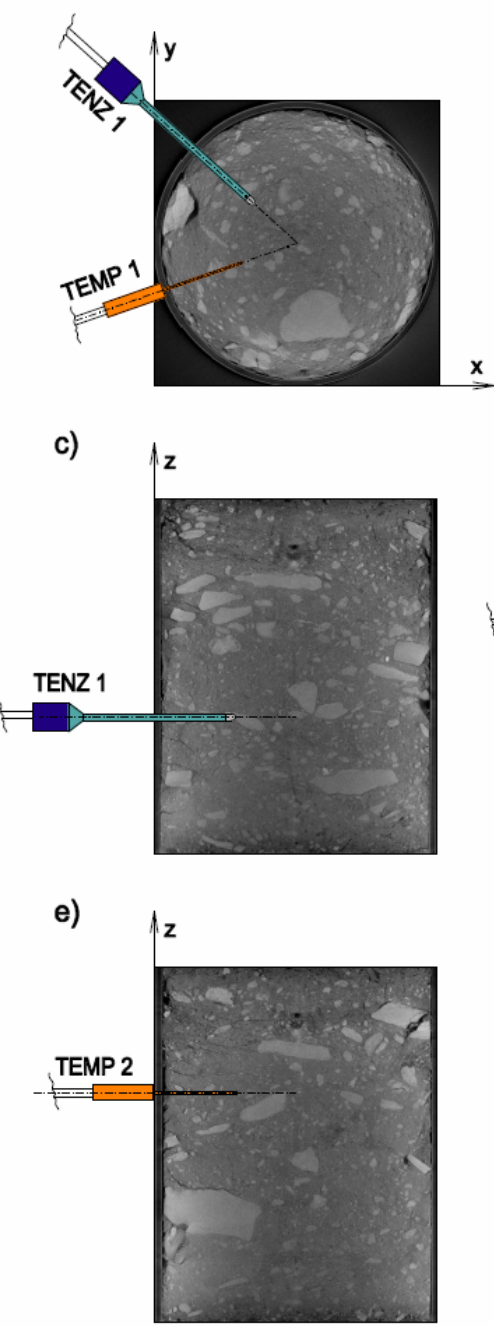

$k=\frac{\mu K_{S}}{\rho g}$

where $k$ is the permeability $\left(\mathrm{m}^{2}\right)$, not dependent on liquid properties, $\rho$ is the liquid density $\left(\mathrm{kg} . \mathrm{m}^{-3}\right), g$ is the gravitational acceleration (m. $\mathrm{s}^{-2}$ ), and $\mu$ is the dynamic viscosity of the liquid $\left(\mathrm{N} . \mathrm{s.m}^{-2}\right)$ and $K_{S}$ is the saturated hydraulic conductivity. As both $\mu$ and $\rho$ depend on temperature, their values were adjusted for each infiltration experiment represented by the known temperature of the effluent water using the following formulas for viscosity (Kestin et al., 1981):

$$
\mu=\frac{1.79 \cdot 10^{-6}}{1+0.0337 \cdot T+0.000221 \cdot T^{2}}
$$

where $T$ is the liquid temperature $\left({ }^{\circ} \mathrm{C}\right)$ and for the density of the water

$$
\rho=1000 \cdot\left[1-\frac{T+288.9414}{508929.2 \cdot(T+68.12963)} \cdot(T-3.9863)^{2}\right]
$$

\section{b) $153 \mathrm{~mm}$}

\section{below surface}

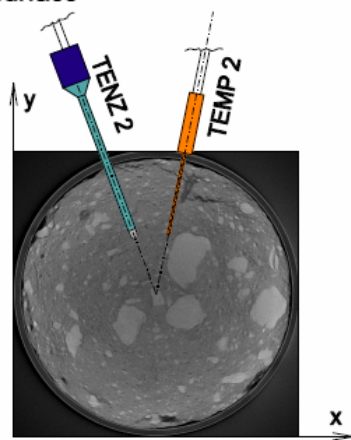

d)

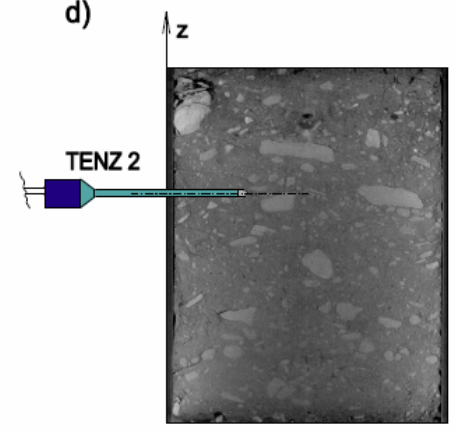

f)

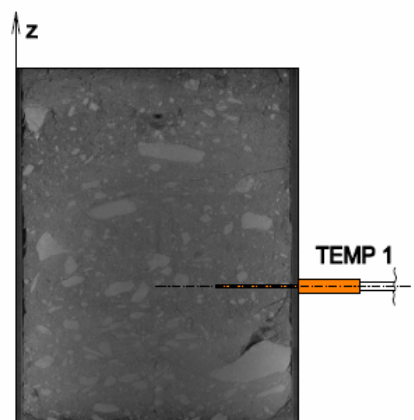

Fig. 2. X-ray computed tomography images of the sample from site Roklan and location of the tensiometers (TENZ) and temperature sensors (TEMP) position. a) Horizontal slice in depth $88 \mathrm{~mm}$ below surface with indicated position of the tensiometer and temperature sensor, b) the same for depth of $153 \mathrm{~mm}$ below the sample surface, c) and d) position of the tensiometers in corresponding vertical slices and e) and f) the location of temperature sensors in corresponding vertical slices are shown. 
Table 1. Porosity and van Genuchten model parameters for retention curve from Roklan site.

\begin{tabular}{|c|c|c|c|c|c|c|}
\hline $\begin{array}{l}\text { Depth below surface } \\
\text { (cm) }\end{array}$ & $\begin{array}{l}\text { Corresponding depth in the soil core } \\
(\mathrm{cm})\end{array}$ & $\begin{array}{c}\theta_{r} \\
\left(\mathrm{~cm}^{3} \cdot \mathrm{cm}^{-3}\right)\end{array}$ & $\begin{array}{c}\theta_{s} \\
\left(\mathrm{~cm}^{3} \cdot \mathrm{cm}^{-3}\right)\end{array}$ & $\begin{array}{c}\alpha \\
(1 / \mathrm{cm})\end{array}$ & $\begin{array}{c}n \\
(-)\end{array}$ & $p$ \\
\hline $15-30$ & $0-10$ & 0.157 & 0.551 & 0.108 & 1.269 & 0.52 \\
\hline $30-45$ & $10-25$ & 0.156 & 0.484 & 0.039 & 1.231 & 0.53 \\
\hline
\end{tabular}

\section{RESULTS AND DISCUSSION Soil properties}

The grain size analysis revealed that the soil consists of $10 \%$ clay, $20 \%$ silt and $70 \%$ sand. The particle density was $2.69 \mathrm{~g} . \mathrm{cm}^{-3}$. The soil was classified as sandy loam according to the USDA classification triangle. Van Genuchten parameters of soil water retention curves $\left(\theta_{r}, \theta_{s}, \alpha, n\right)$ for the Roklan experimental site, are shown in Table 1 . The soil parameters are similar to those obtained for experimental catchments in the Sumava Mountains (e.g. Votrubová et al., 2012). The low value of parameter $n$ that is typical for mountainous soils formed on crystalline bedrock (Dohnal et al., 2010) was indicated. As expected, the saturated water content was lower for the layer representing the lower portion of the sample, but properties of the sample can be viewed as fairly uniform along its height. Figure 3 shows retention curves measured on small undisturbed samples from Roklan. Triplicate sets of small columns for each depth were collected. One chosen retention curve was fitted through the use of the RETC program for all sampled depths (van Genuchten et al., 1991).

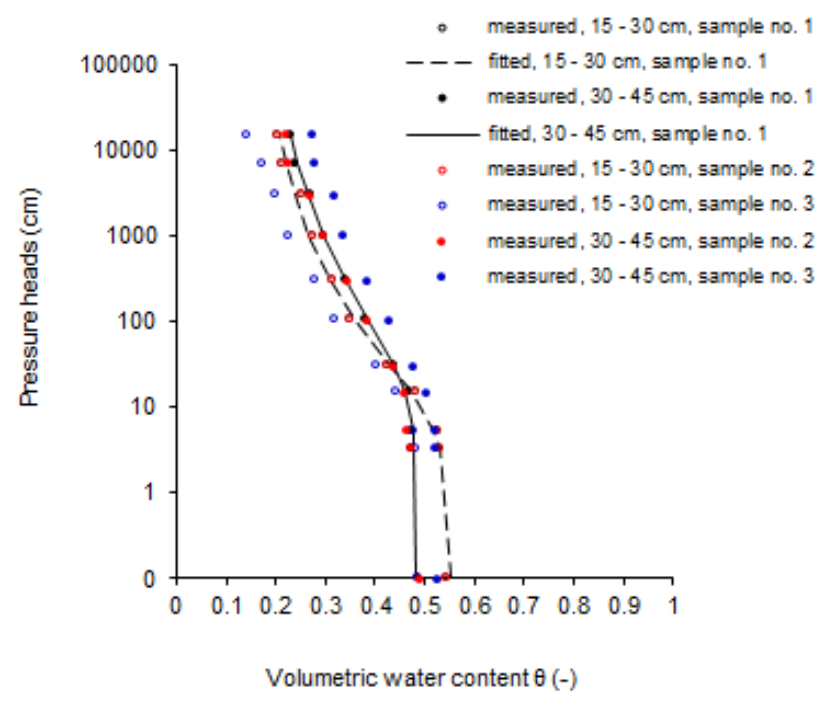

Fig. 3. Measured points of retention curves of small samples from Roklan site. Chosen retention curve was fitted (fitted points)

\section{Infiltration-outflow experiments with deuterium breakthrough}

For all infiltration experiments, the sample was dried using air flow before the start of the infiltration until the pressure heads reached a tension similar to the values that naturally occur in the Roklan site in the periods between rain events. For the case of the near-isothermal infiltration experiment (R-I), the pressure heads before the start of the infiltration were $-265 \mathrm{~cm}$ for tensiometer P1 and $-243 \mathrm{~cm}$ for tensiometer P2.

The outcome of monitoring the temperatures in the water above the sample, inside the soil and in the effluent during the R-I experiment is shown in Figure 4a.
For the non-isothermal infiltration-outflow experiment (R-N-1) and the repeated non-isothermal infiltration-outflow experiment (R-N-2), the sample was dried by an upward flow of air prior to infiltration to a similar initial pressure head as in the case of the non-isothermal experiment. The pressure heads measured by tensiometers ranged from $-225 \mathrm{~cm}$ (P1) to $-221 \mathrm{~cm}(\mathrm{P} 2)$ for the R-N-1 experiment and from $-234 \mathrm{~cm}(\mathrm{P} 1)$ to $-215 \mathrm{~cm}(\mathrm{P} 2)$ for the R-N-2 experiment.

Figure $3 \mathrm{~b}$ shows that the temperature in the depth of $8.3 \mathrm{~cm}$ below the surface dropped from an initial $25^{\circ} \mathrm{C}$ to $10^{\circ} \mathrm{C}$ during the entire course of the R-N-1 experiment and from $23^{\circ} \mathrm{C}$ to $6^{\circ} \mathrm{C}$ during the R-N-2 experiment. The temperature in the deeper temperature sensor, placed $15.3 \mathrm{~cm}$ below the surface gradually decreased from $23^{\circ} \mathrm{C}$ to $9^{\circ} \mathrm{C}$ for the R-N-1 experiment and from $23^{\circ} \mathrm{C}$ to $6^{\circ} \mathrm{C}$ for the R-N-2 experiment. Note that temperature peaks recorded in the ponding water and in the sample were caused by the delivery of water which, being stagnant, became warmer in the tubing during the inactive state.

The time development of the pressure heads indicated by shallower tensiometer P1 was very similar in all three experiments. The wetting front reached the tip of the tensiometer between 1.5 and 2.5 minutes and subsequently the zero pressure head reading was reached less than 4 minutes after beginning the infiltration. The deeper tensiometer P2 exhibited more variations, with pressure head build-up being the same as in tensiometer $\mathrm{P} 1$ in the case of experiment $\mathrm{R}-\mathrm{N}-1$, reacting faster than $\mathrm{P} 1$ in the case of experiment R-I and reacting slowly in the case of experiment R-N-2. In the latter case, the tensiometer reaction is likely being affected by an air bubble in the body of the tensiometer. During the steady-state flow stage of the experiment, the tensiometers indicate values close to zero as expected. Small peaks of negative pressures only occur after warmer water passes through the sample when the pumps are switched.

Figure 5 indicates that in the case of the isothermal (R-I) experiment, the outflow flux density reached the maximum value $0.67 \mathrm{~cm} . \mathrm{min}^{-1}$ soon after the experiment began. The outflow rate then gradually decreased to $0.38 \mathrm{~cm} \mathrm{~min}^{-1}$, which represents a $32 \%$ decline from the maximum value.

Figure 5 shows that during the non-isothermal (R-N-1) experiment the outflow rate reached $0.42 \mathrm{~cm} \cdot \mathrm{min}^{-1}$ after rising during the first 18 minutes. Similarly, the outflow rate reached $0.41 \mathrm{~cm} \cdot \mathrm{min}^{-1}$ for the replicated R-N-2 experiment. Then, the flow rate was mostly steady during the rest of the experiment, with the exception of two small peaks that corresponded to the temporary period of the infiltration of warmer water when the peristaltic pumps were switched. The flux density recorded during the repeated non-isothermal R-N-2 experiment exhibited the same decline observed during the isothermal R-I experiment, but after 90 minutes it then increased back to the initial values. Before the end of infiltration, the flow rate of all three experiments was almost equal. The results are in contradiction with the findings of e.g. Levy et al. (1989), who found that hydraulic conductivity is temperature dependent and should increase with an increase in water temperature mainly in response to the decreasing viscosity of the water (Haridasan and Jensen, 1972). Our non-isothermal experiments do not clearly indicate a decline of the flux density due to the decline of viscosity. 

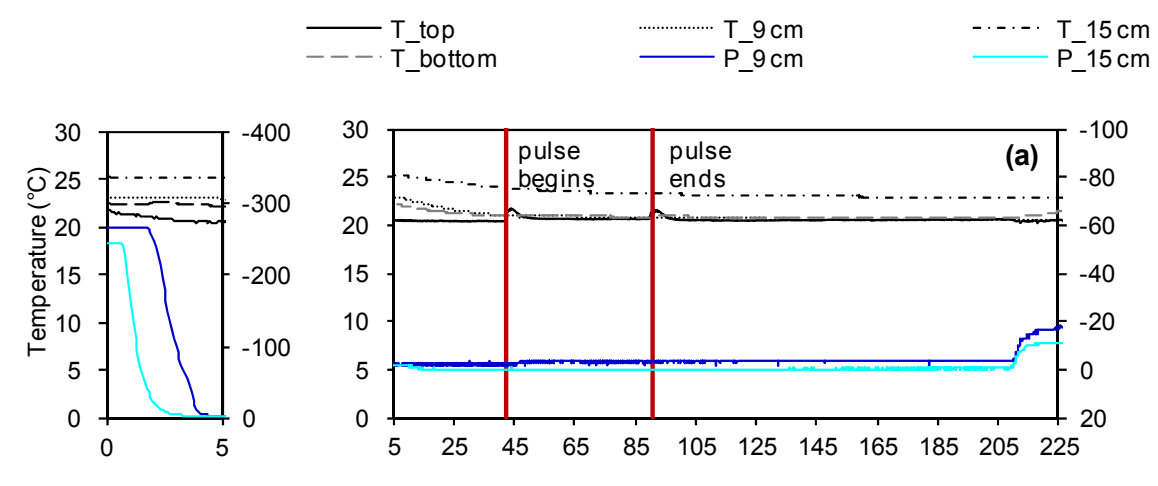

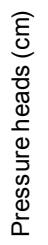
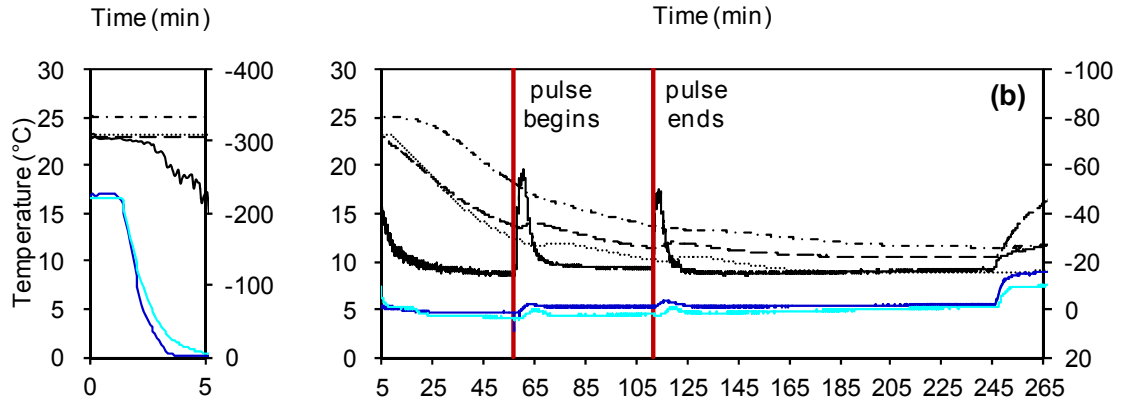

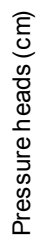

Time $(\min )$

Time $(\min )$
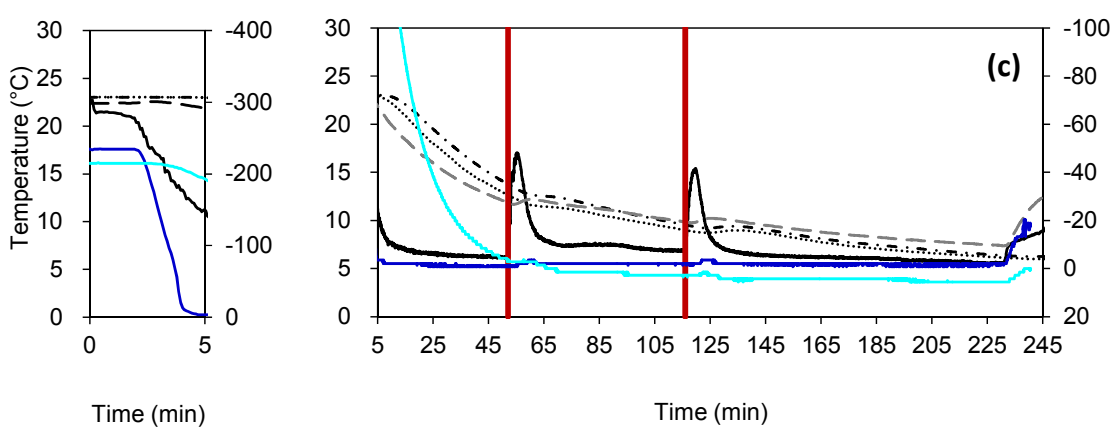

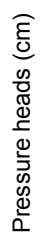

Time ( $\min )$

Time $(\min )$

Fig. 4. Temperature of water level on the top of the soil core (T top), inside (T $9 \mathrm{~cm}, \mathrm{~T} 15 \mathrm{~cm})$ and on the outflow (T bottom), and pressure heads (P_9 cm, P_15 cm) during near-isothermal, R-I (a), non-isothermal R-N-1 (b), and non-isothermal repeated R-N-2 (c) infiltration-outflow experiments. Detailed view of first 5 minutes of each infiltration is shown on the left.

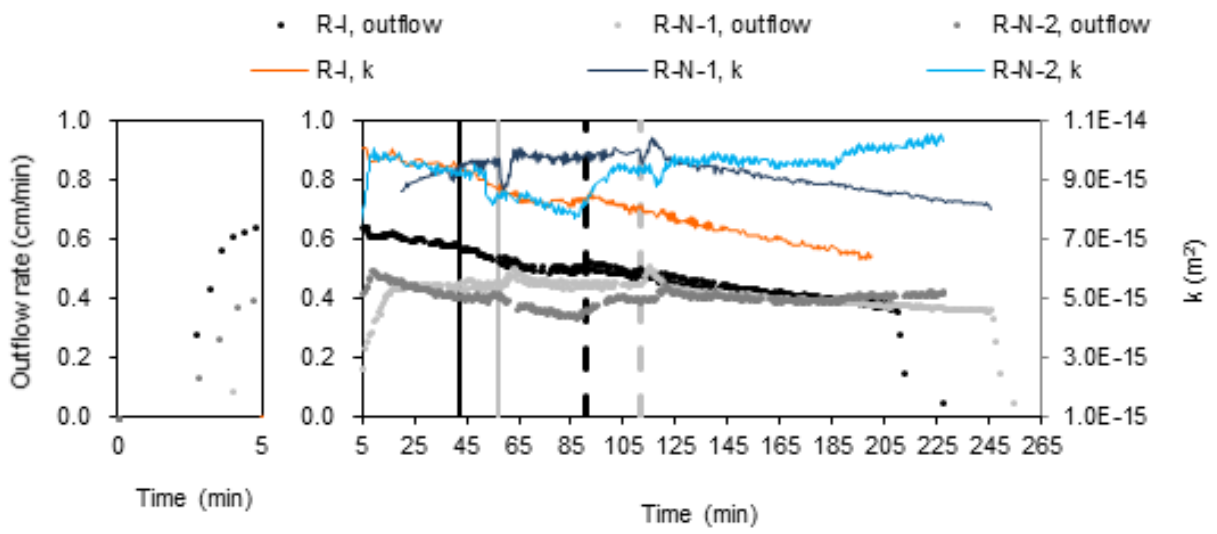

Fig. 5. Outflow rates during near-isothermal (R-I), non-isothermal (R-N-1) and repeated non-isothermal (R-N-2) infiltration-outflow experiments along with calculated permeability $k$. Beginning and end of the deuterium concentration pulses are depicted by vertical lines. Detailed view of first 5 minutes of each infiltration is shown on the left.

To assess whether the observed changes of outflow rates could be explained by changes of the viscosity and density of the water, the soil permeability was determined on the assumption of a steady state flow through the sample, considering the validity of Darcy's law and Equations 3 through 5. The mean value of the temperatures of the inflow and outflow water was used for the calculation of $k$. The results are plotted for relevant periods of both infiltration runs in Figure 5. In theory, the per- 
meability of the soil should be independent from properties of the liquid and thus the permeability calculated from steady-state fluxes and corrected for density and viscosity changes should be constant and the same for all three experiments.

It is however clearly visible that the value $k$ was changing over time during the steady-state flow stages of all three experiments. The trends of $k$ are different for the different experiments. The flux density was gradually decreasing in the case of the near-isothermal infiltration experiment and therefore, since very little temperature correction was done in this case, permeability followed the same trend. The decreasing trend in the flow rate during the steady state stage of the infiltration experiment, observed in the near-isothermal experiment, was repeatedly reported for coarse sandy loams by Císlerová et al. (1988). It was demonstrated by Sněhota et al. (2015) that this effect is caused by the transfer of trapped air bubbles from regions of the fine soil material to preferential pathways that gradually become blocked. The trend of the decreasing flux density and permeability observed in the R-N-2 experiment is similar to the near-isothermal case during the first 90 minutes. Then, the measured $k$ value rose abruptly for approximately 20 minutes until it reached the values from the beginning of the steadystate phase of the experiment. The rest of the experiment showed a gradual increase of $k$ mostly due to the continued decrease of the temperature of the flowing water.

The R-N-1 experiment, on the contrary, displayed different behavior. Firstly, the time needed to reach the steady state flow was longer in this experiment than in experiments R-I and $\mathrm{R}-\mathrm{N}-2$ by approximately 10 minutes. The flow rate remained almost constant until the concentration pulse was applied. It seems that the water flux increased slightly each time the flow started to be provided by the new pump. It is reasonable to assume that the flux density increased temporarily due to a short term temperature peak and the corresponding low viscosity induced by water warmed up in the tubing during the period of inactivity. Similar peaks in the water flux density were observed in the case of the second non-isothermal experiment $\mathrm{R}-\mathrm{N}-2$, but they were nonexistent in the near-isothermal experiment R-I. The peaks on the water flux density curve are also clearly visible like the peaks on the permeability curve in most cases in the inverse direction to the direction of the water flux density. Permeability was almost the same in both nonisothermal experiments immediately after the end of applying the concentration pulse. Then, the $k$ value was gradually decreasing during the rest of the R-N-1 experiment. Summarizing the results of the three experiments, the $k$ value was similarly close to the value of $9 \times 10^{-15} \mathrm{~m}^{2}$ at the beginning of the steadystate stages of the experiments, while at the end, after approximately 200 minutes of infiltration, $k$ was significantly lower in the case of the near-isothermal experiment $\left(6.4 \times 10^{-15} \mathrm{~m}^{2}\right)$, that for the non-isothermal infiltration experiments (between $8.7 \times 10^{-15}$ and $9.9 \times 10^{-15} \mathrm{~m}^{2}$ ).

The results do not support the hypothesis of the growth of bubbles in the sample due to the warming of the infiltrating cold water and the corresponding decrease of air solubility in the water with expected bubbles accumulating in the pores of the soil.

The alternative explanation would be that air bubbles, initially trapped in the pore system gradually shrink in response to the cooling from the flowing water, thus opening the flow channels initially blocked by the air. According to the ideal gas law, air at atmospheric pressure contracts by about $4.7 \%$ when cooled down from 24.2 to $10.2^{\circ} \mathrm{C}$ which was, for example the effluent water temperature drop during the non-isothermal infiltrationoutflow experiment $\mathrm{R}-\mathrm{N}-1$. This effect of the contraction of the

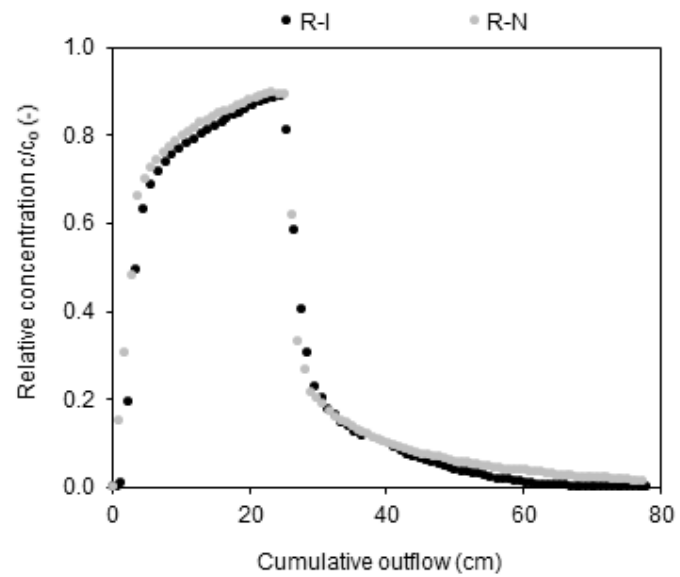

Fig. 6. Observed points of $\delta^{2} \mathrm{H}$ breakthrough curves done on the soil column R1L during the isothermal (R-I) and non-isothermal (R-N) infiltration-outflow experiments.

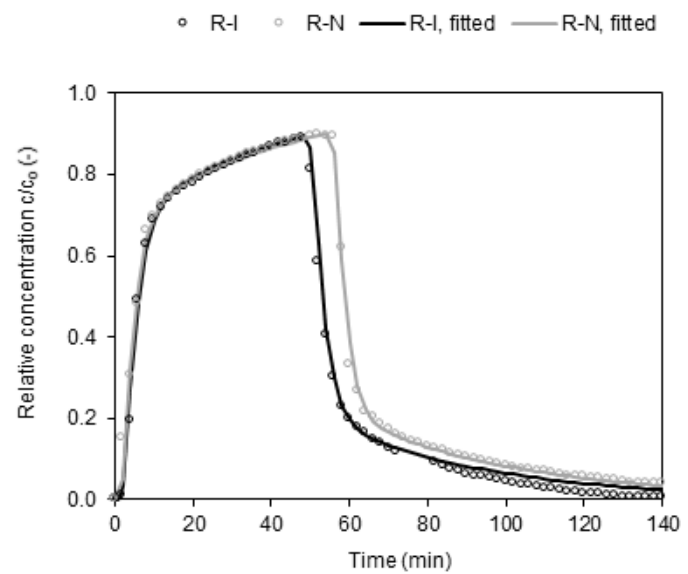

Fig. 7. Observed (symbols) and fitted (lines) deuterium breakthrough curves during near-isothermal and non-isothermal infiltration-outflow experiments.

bubbles could be further strengthened by the increased curvature of the surface of the bubbles and the corresponding increase in air pressure. This mechanism might also explain the increase of permeability after 90 minutes in the case of experiment R-N-2. It was found by Dohnal et al. (2013) that the spatial distribution of entrapped air clusters in the structured soil has a greater impact on the overall soil permeability than the total entrapped air saturation. Therefore, it is possible that entrapped air bubble shrinkage in the highly conductive, interconnected macropore can significantly increase the conductivity of such structures and this change can be relatively rapid, as in the case of the observed rise of the permeability of the sample under study during the infiltration R-N-2.

\section{Deuterium breakthrough}

Deuterium is an ideal conservative natural tracer (Šanda et al., 2014) usable for breakthrough studies when water is spiked with deuterium oxide. The pulse of the deuterium solution was applied during the near-steady-state flow of experiment R-I, $\mathrm{R}-\mathrm{N}-1$ and R-N-2. Analysis of the breakthrough curves (BTC) was done for experiments R-I and R-N-1. The BTC of experiment R-N-2 could not be analyzed due to technical issues. The timing of the application of the pulses is indicated in Figure 3 by red vertical lines. The relative concentration of $\delta^{2} \mathrm{H}$ was 
plotted against the cumulative outflow in Figure 6. The shape of these BTCs shows a steep concentration rise and long tailing which indicates a physical non-equilibrium of the solute transport and water fractionation between the mobile and immobile domains and was expected for heterogeneous soil with preferential pathways (e.g. Larsbo et al., 2014). The shape of the BTCs for the near-isothermal and non-isothermal R-N-1 infiltration experiments are nearly identical when relative concentrations are plotted against the cumulative outflow.

\section{Deuterium transport parameters}

Table 2 summarizes the estimated transport parameters of both experimental runs using a two-region non-equilibrium model implemented in CXTFIT code. It can be seen that the transport parameters of the near-isothermal and non-isothermal experiments are nearly identical with the exception of mobile water fraction $f_{m}$, which was slightly higher in the case of nearisothermal conditions. The estimated values of $f_{m}$ suggest a well-developed non-equilibrium transport regime. Under such conditions, about one-third of the water pore system is mobile and participates in deuterium flux from the sample, while the remaining water is stagnant and serves only as deuterium storage. The estimated mass transfer coefficients were smaller than found in the literature (e.g., Köhne et al., 2004), indicating notable non-equilibrium conditions (Nielsen et al., 1986). The fast appearance of deuterium in leachate and the long tailing of the breakthrough curves are clear characteristics of a nonequilibrium transport regime (Figure 7). The solute transport parameters estimated for isothermal and non-isothermal conditions suggests that the distribution of pore sizes conducting water did not change significantly, which was not expected. The results suggest that if the change in the temperature reduces the bubble size and amplifies the flux, it still does not affect drastically the flow paths distribution, because the bubbles are probably affected in the same way in smaller and larger pores, despite a slightly higher mobile water fraction $f_{m}$ for isothermal experiment, suggesting a reduction of bubbles slightly more efficient in the preferential pathways.

Table 2. Estimated parameters of deuterium transport. R-I and R-N stand for near-isothermal and non-isothermal infiltration experiment, respectively.

\begin{tabular}{lccccc}
\hline Run & $v\left(\mathrm{~cm} \mathrm{~min}^{-1}\right) \dagger$ & $\lambda(\mathrm{cm})$ & $f_{\mathrm{m}}(-)$ & $\alpha\left(\mathrm{min}^{-1}\right)$ & $R^{2}(-)$ \\
\hline R-I & 1.43 & 4.38 & 0.35 & $3.77 \mathrm{E}-4$ & 0.997 \\
R-N & 1.38 & 4.54 & 0.31 & $3.75 \mathrm{E}-4$ & 0.998 \\
\hline
\end{tabular}

$\dagger v-$ mean pore water velocity, $\lambda-$ dispersivity, $f_{m}-$ fraction of mobile water, $\alpha$-mass transfer coefficient, $R^{2}-$ coefficient of determination

\section{CONCLUSIONS}

This study shows results of infiltration-outflow experiments on an undisturbed soil column with the infiltration of water at a temperature close to the initial temperature of the soil and the infiltration of water significantly colder. The temperature of the soil at the beginning of the experiment was similar in all cases. The breakthrough curve of deuterium was additionally measured in two experiments. The following summary can be drawn from the experimental results:

a) Absolute values as well as trends of the soil permeability, calculated from the water flux densities measured during the course of the experiments and with regard to temperature induced changes of viscosity and density of the water exhibited significant variability. The theoretical dependence of viscosity and density of water could not explain the changes in water flow as a response to imposed temperature gradients.

b) The soil permeability was generally higher in cases of infiltration of cold water especially at the end of the experiment, when the temperature of the soil and the water came into equilibrium.

c) Despite the differences in steady-state flow rates, the deuterium tracer transport was not affected.

Conducting further experiments on simpler types of porous media such as sand will be necessary to evaluate the possible reasons for the increased permeability by the contraction of air bubbles due to the decrease in temperature. A non-invasive method such as $\mathrm{x}$-ray microtomography should be utilized to track the spatial distribution of air bubbles during future experiments.

Data from this complex experiment involving the variably saturated transport of water, solute, and heat on natural soil can be used for the evaluation of numerical models dealing with these processes (e.g. Fučík et al., 2017; Vogel et al., 2011).

Acknowledgements. This work has been supported by the Ministry of Education, Youth and Sports within National Sustainability Programme I, project No. LO1605 and by the Czech Science Foundation under Grant no. 14-03691S and no. 1605665S. It has been also supported by Grant Agency of the Czech Technical University in Prague, SGS16/143/OHK1/2T/11. The authors are grateful to Dr. Martin Sanda for analyzing $\delta^{2} \mathrm{H}$ samples. We thank Dr. John Koestel from the Swedish University of Agricultural Sciences, Uppsala, for performing the computer tomography imaging of the sample.

The data presented in this publication can be provided on request.

\section{REFERENCES}

Angulo-Jaramillo, R., Bagarello, V., Iovino, M., Lassabatere, L., 2016. Infiltration Measurements for Soil Hydraulic Characterization. Springer.

Braga, A., Horst, M., Traver, R.G., 2007. Temperature effects on the infiltration rate through an infiltration basin BMP. Journal of Irrigation and Drainage ASCE, 133, 6, 593-601.

Buchner, J.S., Simunek, J., Lee, J., Rolston, D.E., Hopmans, J.W., King, A.P., Six, J., 2008. Evaluation of $\mathrm{CO}_{2}$ fluxes from an agricultural field using a process based numerical model. Journal of Hydrology, 3, 61, 131-143.

Císlerová, M., Šimůnek, J., Vogel, T., 1988. Changes of steadystate infiltration rates in recurrent ponding infiltration experiments. Journal of Hydrology, 104, 1-4, 1-16.

Constanz, J., 1982. Temperature dependence of unsaturated hydraulic conductivity of two soils. Soil Science Society of America Journal, 46, 466-470.

Constanz, J., Murphy, F., 1991. The temperature dependence of ponded infiltration under isothermal conditions. Journal of Hydrology, 122, 1-4, 119-128. DOI: 10.1016/00221694(91)90175-H.

Dohnal, M., Dušek, J., Vogel, T., 2010. Improving hydraulic conductivity estimates from minidisk infiltrometer measurements for soils with wide pore-size distributions. Soil Science Society of America Journal, 74, 3, 804-811. DOI: 10.2136/sssaj2009.0099.

Dohnal, M., Jelínková, V., Sněhota, M., Dušek, J., Březina J., 2013. Three-dimensional numerical analysis of water flow affected by entrapped air: Application of noninvasive 
imaging techniques. Vadose Zone Journal, 12, 1, vzj2012.0078. DOI: 10.2136/vzj2012.0078.

Duley, F.L., Domingo, C.E., 1943. Effect of water temperature on rate of infiltration. Soil Science Society Proceedings, 8, 129-131.

Faybishenko, B.A., 1995. Hydraulic behavior of quasi-saturated soils in the presence of entrapped air - laboratory experiments. Water Resources Research 31, 10, 2421-2435.

Fučík, R., Klinkovský, J., Solovský, J., Oberhuber, T., Mikyška, J., 2017. Multidimensional mixed-hybrid finite element method for compositional two-phase flow in heterogeneous porous media and its parallel implementation on GPU. Computer Physics Communications (in the review process).

Gerke, H.H., Koszinski, S., Kalettka, T., Sommer, M., 2010. Structures and hydrologic function of soil landscapes with kettle holes using an integrated hydropedological approach. Journal of Hydrology 393, 1-2, 123-132.

Gerla, P.J., 1992. The relationship of water-table changes to the capillary-fringe, evapotranspiration, and precipitation in intermittent wetlands. Wetlands, 12, 2, 91-98.

Haberer, C.M., Rolle, M., Liu, S., Cirpka, O.A., Grathwohl, P., 2011. A high-resolution non-invasive approach to quantify oxygen transport across the capillary fringe and within the underlying groundwater. Journal of Contaminant Hydrology, $122,1-4,26-39$.

Haridasan, M., Jensen, R.D., 1972. Effect of temperature on pressure, head-water content relationship and conductivity of two soils. Soil Science Society of America Journal, 36, 5, 703-708. DOI: 10.2136/sssaj1972.03615995003600050011x.

Hillel, D., 1998. Environmental Soil Physics. Academic Press. $771 \mathrm{p}$.

Hopmans, J.W., Dane, J.H., 1986. Temperature dependence of soil hydraulic properties. Soil Science Society of America Journal, 50, 4-9.

Jaynes, D.B., 1990. Temperature variations effect on fieldmeasured infiltration. Soil Science Society of America Journal, 54, 305-312. DOI: 10.2136/sssaj1990.03615995005400020002x.

Jury, W.A., Horton, R., 2004. Soil Physics. 6th ed. J. Wiley, Hoboken, NJ.

Kestin, J., Khalifam H.E., Correia, R.J., 1981. Tables of the dynamic and kinematic viscosity of aqueous $\mathrm{KCl}$ solutions in the temperature range $25-150^{\circ} \mathrm{c}$ and the pressure range 0.1 - 35 MPa. J. Phys. Chem. Ref. Data, 10, 1.

Koestel, J., Jorda, H., 2014. What determines the strength of preferential transport in undisturbed soil under steady-state flow? Geoderma, 217, 144-160. DOI: 10.1016/j.geoderma.2013.11.009.

Köhne, J.M., Köhne, S., Mohanty, B.P., Šimůnek, J., 2004. Inverse mobile-immobile modeling of transport during transient flow. Vadose Zone Journal, 3, 4, 1309-1321.

Larsbo, M., Koestel, J., Jarvis, N., 2014. Relations between macropore network characteristics and the degree of preferential solute transport. Hydrology and Earth System Sciences, 18, 12, 5255-5269. DOI: 10.5194/hess-18-52552014.

Levy, G.J., Smith, H.J.C., Agassi, M., 1989. Water temperature effect on hydraulic conductivity and infiltration rate of soils. South African Journal of Plant and Soil, 6, 4, 240-244. DOI: 10.1080/02571862.1989.10634520.

Lin, C., Greenwald, D., Banin, A., 2003. Temperature dependence of infiltration rate during large scale water recharge into soils. Science Society of America Journal, 67, 487-493. DOI: $10.2136 /$ sssaj2003.4870.
Nielsen, D.R., van Genuchten, M.T., Biggar, J.W., 1986. Water flow and solute transport processes in the unsaturated zone. Water Resources Research, 22, 89S-108S.

Nielsen, P., Aseervatham, R., Fenton, J.D., Perrochet, P., 1997. Groundwater waves in aquifers of intermediate depths. Advances in Water Resources, 20, 1, 37-43.

Penna, D., Stenni, B., Šanda, M., Wrede, S., Bogaard, T.A., Gobbi, A., Borga, M., Fischer, B.M.C., Bonazza, M., Chárová, Z., 2010. On the reproducibility and repeatability of laser absorption spectroscopy measurements for $\delta^{2} \mathrm{H}$ and $\delta^{18} \mathrm{O}$ isotopic analysis. Hydrology and Earth System Science, 14, 1551-1566.

Saha, R.S., Tripathi, R.P., 1979. Effect of temperature on hydraulic conductivity of soil. Journal of the Indian Society of Soil Science, 27, 3, 220-224.

Saito, H., Šimůnek, J., Mohanty, B.P., 2006. Numerical analysis of coupled water, vapor, and heat transport in the vadose zone. Vadose Zone J., 5, 784-800.

Šanda, M., Vitvar, T., Kulasová, A., Jankovec, J., Císlerová, M., 2014. Run-off formation in a humid, temperate headwater catchment using a combined hydrological, hydrochemical and isotopic approach (Jizera Mountains, Czech Republic). Hydrological Processes, 28, 8, 3217-3229.

Silliman, S.E., Berkowitz, B., Simunek, J., van Genuchten, M.T., 2002. Fluid flow and solute migration within the capillary fringe. Ground Water, 40, 1, 76-84.

Simunek, J., van Genuchten, M.Th., Sejna, M., Toride, N. Leij, F.J., 1999. The STANMOD computer software for evaluating solute transport in porous media using analytical solutions of convection-dispersion equation. Versions 1.0 and 2.0, IGWMC - TPS - 71, International Ground Water Modeling Center, Colorado School of Mines, Golden, Colorado, $32 \mathrm{p}$.

Snehota, M., Sobotkova, M., Cislerova, M., 2008. Impact of the entrapped air on water flow and solute transport in heterogeneous soil: experimental set-up. Journal of Hydrology and Hydromechanics, 56, 4, 247-256.

Sněhota, M., Jelínková, V., Sobotková, M., Šácha, J., Vontobel, P., Hovind, J., 2015. Water and entrapped air redistribution in heterogeneous sand sample: Quantitative neutron imaging of the process. 51, 1359-1371. DOI: 10.1002/2014WR015432.

Sobotkova, M., Snehota, M., 2014. Method of in-line bromide breakthrough curve measurements for column leaching experiments. Vadose Zone Journal, 13, 8. DOI: 10.2136/vzj2013.11.0192.

Tesař, M., Šír, M., Lichner, L., Zelenková, E., 2006. Influence of vegetation cover on thermal regime of mountainous catchments. Biologia, 61, Suppl. 19, S311-S314.

Tesař, M., Šír, M., Krejča, M., Váchal, J., 2008. Influence of vegetation cover on air and soil temperatures in the Sumava Mts. (Czech Republic). IOP Conference Series: Earth and Environmental Science, 4, 012029. DOI: 10.1088/17551307/4/1/012029.

Toride, N., Leij, F.J., van Genuchten, M.T., 1995. The CXTFIT code for estimating transport parameters from laboratory or field tracer experiments. Version 2.0, Research Report No. 137, U. S. Salinity Laboratory, USDA, ARS, Riverside, CA.

Ungureanu, A., Statescu, F., Sněhota, M., Sobotková, M., 2012. Experimental research on flow and solute transport in heterogeneous soil sample. Environmental Engineering and Management Journal, 11, 5, 1023-1028.

van Genuchten, M.T., 1980. A closed-form equation for predicting the hydraulic conductivity of unsaturated soils. Soil Science Society of America Journal, 44, 892-898. 
van Genuchten, M.T., 1981. Non-equilibrium transport parameters from miscible displacement experiments. Research Report No. 119, U.S. Salinity Laboratory, USDA, ARS, Riverside, $\mathrm{CA}$.

van Genuchten, M.T., Leij, F.J., Yates, S.R., Williams, J.R., 1991. The RETC Code for Quantifying Hydraulic Functions of Unsaturated Soils. EPA/600/2-91/065, U.S. Salinity Laboratory, Riverside, California. IAG-DW12933934.

van Genuchten, M.T., Šimůnek, J., Leij, F.L., Toride, N., Šejna, M., 2012. STANMOD: Model use, calibration and validation. Transactions of the ASABE, 5, 4, 1353-1366.
Vogel, T., Dohnal, M., Votrubová, J., 2011. Modeling heat fluxes in macroporous soil under sparse young forest of temperate humid climate. Journal of Hydrology, 402, 4, 367-376. ISSN 0022-1694.

Votrubová, J., Dohnal, M., Vogel, T., Tesař, M., 2012. On parameterization of heat conduction in coupled soil water and heat flow modelling. Soil and Water Research, 7, 4, $125-137$.

Received 15 August 2016

Accepted 13 May 2017 